\title{
KARAKTERISTIK LEMBAGA KONSINYASI DALAM PENGADAAN TANAH UNTUK KEPENTINGAN UMUM
}

\author{
Tantri Noviana Herawati, Ghansham Anand \\ Magister Kenotariatan, Fakultas Hukum, Universitas Narotama Surabaya \\ Email : tantri.jurnal2018@.gmail.com; gansam anand@ymail.com
}

\begin{abstract}
The social function of land has become one of the basis for Government's policy to put public interest on top of the individual ones, with regard to rights of the individuals. The main purpose of land procurement for public interest is to provide land for the development, in order to increase the welfare and prosperity of the nation. Despite this notion, any legal interest of the parties concerned must still be guaranteed. To guard the public interest, it is necessary to give compensation to any rightsholder whose land has been acquisited by the government. The land procurement process shall be carried out in accordance with the legal regulations concerned, especially Law Number 2 of 2012 about Land Procurement for Public Utilities Construction. In case the rightsholder refuses to accept the form and/or the value of compensation that has been negotiated previously, the government regulated that the compensation shall be commended in a District Court.
\end{abstract}

Keywords : Social Function, Compensation, Consignment.

\begin{abstract}
ABSTRAK
Fungsi sosial tanah telah menjadi salah satu dasar kebijakan Pemerintah untuk menempatkan kepentingan publik di atas yang individu, berkaitan dengan hak-hak individu. Tujuan utama pengadaan tanah untuk kepentingan umum adalah menyediakan lahan untuk pembangunan, untuk meningkatkan kesejahteraan dan kemakmuran bangsa. Terlepas dari pengertian ini, setiap kepentingan hukum dari pihak-pihak terkait masih harus dijamin. Untuk menjaga kepentingan publik, perlu memberikan kompensasi kepada pemegang hak cipta yang tanahnya telah diakuisisi oleh pemerintah. Proses pengadaan tanah harus dilakukan sesuai dengan peraturan hukum yang bersangkutan, khususnya Undang-Undang Nomor 2 Tahun 2012 tentang Pengadaan Tanah untuk Pembangunan Utilitas Umum. Jika pemegang hak menolak untuk menerima nilai kompensasi yang telah dinegosiasikan sebelumnya maka pemerintah mengatur bahwa kompensasi akan dititipkan di Pengadilan Negeri.
\end{abstract}

Kata kunci: Fungsi Sosial, Kompensasi, Konsinyasi. 


\section{PENDAHULUAN}

Pertumbuhan penduduk yang meningkat pesat tidak didukung dengan persediaan sumber daya tanah yang terbatas. Kondisi demikian mengakibatkan pelaksanaan pembangunan untuk kepentingan umum yang telah direncanakan oleh pemerintah seringkali berbenturan dengan hak perseorangan atas tanah. Pada akhirnya, demi memenuhi kebutuhan tanah untuk keperluan pembangunan, pemerintah melakukan pengambilalihan tanah-tanah hak perseorangan. Dasar pengambilalihan tanah hak perseorangan untuk kepentingan umum didasarkan kepada ketentuan Pasal 6 UUPA yang menentukan bahwa "Semua hak atas tanah mempunyai fungsi sosial". Fungsi sosial tanah bermakna bahwa hak atas tanah perseorangan tidak bersifat mutlak. Hak atas tanah tidak dibenarkan dipergunakan semata-mata untuk kepentingan pribadi, melainkan harus sesuai dengan keadaan dan sifat daripada haknya, sehingga bermanfaat baik bagi kesejahteraan yang mempunyainya maupun bermanfaat bagi masyarakat dan Negara.

Pada dasarnya ha katas tanah seseorang tidak hanya mempunyai manfaat bagi pemilik hak atas tanah melainkan bagi seluruh bangsa Indonesia. Tanah tidak hanya mempunyai nilai ekonomis tetapi juga fungsi sosial, oleh karena itu kepentingan pribadi atas tanah tersebut dikorbankan guna kepentingan umum. Ini dilakukan dengan cara pelepasan hak atas tanah dengan mendapat ganti kerugian yang tidak hanya berupa uang semata melainkan berupa penggantian tanah atau bentuk lain yang dikehendaki para pihak.

Konsekuensinya adalah dalam hal mempergunakan tanah, yang bersangkutan tidak hanya berpedoman pada kepentingan individu saja tetapi harus memperhatikan kepentingan umum. Pasal 6 UUPA terse-but, hak atas perseorangan dapat dicabut demi kepentingan umum. Ada dua cara yang dapat ditempuh Pemerintah untuk melakukan pengambilalihan hak atas tanah yang dimiliki oleh masyarakat yaitu dengan cara pembebasan/ pelepasan hak atas tanah (prijsgeving) dan cara pencabutan hak atas tanah (onteigening) ${ }^{l}$

Ketentuan mengenai pencabutan hak diatur dalam ketentuan Pasal 18 UUPA,yang menentukan bahwa "Untuk kepentingan umum, termasuk

1 SF. Marbun dan Mahfud MD. PokokPokok Hukum Administrasi Negara. Liberty, Jogjakarta, 2010, h. 164 
kepentingan bangsa dan Negara serta kepentingan bersama dari rakyat, hakhak atas tanah dapat dicabut, dengan memberi ganti kerugian yang layak dan menurut cara yang diatur dengan Undang-undang".

Pengadaan tanah untuk kepentingan umum merupakan tindakan Pemerintah untuk memperoleh tanah yang digunakan untuk berbagai kepentingan pembang-unan, khusunya bagi kepentingan umum. Pada prinsipnya pengadaan tanah untuk kepentingan umum dilakukan dengan cara musyawarah antar para pihak yang memerlukan tanah dengan pemilik hak atas tanah yang tanahnya diperlukan untuk kegiatan pembangunan. ${ }^{2}$

Apabila tanah hak perseorangan diperlukan untuk pembangunan demi kepentingan umum, maka cara pertama yang harus ditempuh pemerintah adalah bermu-syawarah dengan pemegang hak atas ta-nah dan pihak yang berhak untuk mele-paskan tanahnya secara sukarela disertai dengan penggantian kerugian yang telah disepakati. Manakala kesepakatan tersebut tidak tercapai dan lokasi pembangunan tidak dapat

2Herman Hermit, Cara Memperoleh Sertipikat Tanah Hak Milik, Tanah Negara dan Tanah Pemda,Mandar Maju, Bandung, 2004, h. 56 dipindahkan, maka mekanisme pencabutan hak dapat ditempuh.

Berdasarkan ketentuan Pasal 10 dan Penjelasan Umum Bagian II Undang-Undang Nomor 20 Tahun 1961 tentang Pencabutan Hak-Hak atas Tanah dan Benda-Benda Yang Ada Di Atasnya maka dibentuklah lembaga pengadaan tanah yang diatur dalam Peraturan Menteri Dalam Negeri Nomor 15 Tahun 1975 tentang Ketentuan-Ketentuan Mengenai Tata Cara Pembebasan Tanah. Pada tahun berikutnya, pemerintah menerbitkan Peraturan Menteri Dalam Negeri Nomor 2 Tahun 1976 tentang Penggunaan Acara Pembebasan Tanah Untuk Kepentingan Pemerintah Bagi Pembebasan Tanah Oleh Pihak Swasta untuk mengakomodasi kepentingan swasta dalam memperoleh tanah.

Pada tahun 1985 diberlakukan Peraturan Menteri Dalam Negeri Nomor 2 Tahun 1985 tentang Tata Cara Pengadaan Tanah Untuk Keperluan Proyek Pem-bangunan Di Wilayah Kecamatan untuk mendukung pengadaan tanah bagi proyek-proyek pembangunan yang berskala kecil dan tidak memerlukan tanah yang luas, yang dilakukan oleh instansi pemerintah. Pada tahun 1993 Peraturan Menteri Dalam Negeri Nomor 15 Tahun 1975 tentang 
Ketentuan-Ketentuan Mengenai Tata Cara Pembebasan Tanah diganti dengan Keputusan Presiden Nomor 55 Tahun 1993 tentang Pengadaan Tanah Bagi Pelaksanaan Pembangunan Untuk Kepen-tingan Umum. Peraturan pelaksananya dibentuk setahun kemudian yaitu Pera-turan Menteri Negara Agraria/ Kepala BPN Nomor 1 Tahun 1994 tentang Ketentuan Pelaksanaan Keputusan Presi-den Republik Indonesia Nomor 55 Tahun 1993 tentang Pengadaan Tanah Bagi Pelaksanaan Pembangunan Untuk Kepen-tingan Umum. Ketentuan Pasal 17 ayat (2) Keputusan Presiden Nomor 55 Tahun 1993 tentang Pengadaan Tanah Bagi Pe-laksanaan Pembangunan Untuk Kepen-tingan Umum menentukan bahwa dalam hal tanah, bangunan, tanaman atau benda yang berkaitan dengan tanah yang dimiliki bersama oleh beberapa orang, sedangkan satu atau beberapa orang dari mereka tidak dapat ditemukan, maka ganti kerugian yang menjadi hak orang yang tidak dapat diketemukan tersebut, dikonsinyasikan di pengadilan negeri setempat oleh Instansi Pemerintah yang memerlukan tanah.

Ketentuan pasal ini mulai memberlakukan lembaga konsinyasi dalam pelak-sanaan pembayaran uang ganti kerugian kepada pihak berhak yang tidak diketahui keberadaannya. Sebelumnya, tidak ada pengaturan lembaga konsinyasi dalam peraturan pengadaan tanah. Satusatunya lembaga konsinyasi yang dikenal dalam hukum nasional adalah lembaga pena-waran pembayaran tunai yang diikuti dengan konsinyasi dalam hukum perikatan Buku III Kitab Undang-Undang Hukum Perdata Pasal 1404 sampai dengan Pasal 1412 sebagai salah satu cara hapusnya perikatan. Perkembangan selanjutnya, Keputusan Presiden Nomor 55 Tahun 1993 tentang Pengadaan Tanah Bagi Pelaksanaan Pembangunan Untuk Kepen-tingan Umum dicabut dengan Peraturan Presiden Nomor 36 Tahun 2005 tentang Pengadaan Tanah Bagi Pelaksanaan Pem-bangunan Untuk Kepentingan Umum yang kemudian beberapa pasalnya diubah dengan Peraturan Presiden Nomor 65 Tahun 2006 tentang Perubahan Atas Peraturan Presiden Nomor 36 Tahun 2005 tentang Pengadaan Tanah Bagi Pelak-sanaan Pembangunan Untuk Kepentingan Umum. Setahun kemudian, dikeluarkan peraturan pelaksana Peraturan Kepala Badan Pertanahan Nasional Nomor 3 Tahun 2007 Tentang Ketentuan Pelaksanaan Peraturan Presiden Nomor 36 
Tahun 2005 Tentang Pengadaan Tanah Bagi Pelaksanaan Pembangunan Untuk Kepentingan Umum sebagaimana telah diubah dengan Peraturan Presiden Nomor 65 Tahun 2006 tentang Perubahan Atas Peraturan Presiden Nomor 36 Tahun 2005 tentang Pengadaan Tanah Bagi Pelaksana-an Pembangunan Untuk Kepentingan Umum.

Selanjutnya terdapat beberapa kali perubahan peraturan pelaksana, yang dimuat dalam Peraturan Presiden Nomor 71 Tahun 2012 tentang Penyelenggaraan Pengadaan Tanah Bagi Pembanguan Untuk Kepentingan Umum. Yang juga mengalami beberapa kali perubahan diantaranya diatur dalam Peraturan Presiden Nomor 40 Tahun 2012 tentang Perubahan Atas Peraturan Presiden Nomor 71 Tahun 2012 tentang Penyelenggaraan Tanah Bagi Pembangunan Untuk Kepentingan Umum dan yang terakhir diubah dengan Peraturan Presiden Nomor 30 Tahun 2015 tentang Perubahan Ketiga Atas Peraturan Presiden Nomor 71 Tahun 2012 tentang Penyelenggaraan Tanah Bagi Pembangunan Untuk Kepentingan Umum.

Kendala utama yang sering terjadi dalam proses pengadaan tanah untuk kepentingan umum adalah tidak adanya kesepakatan mengenai besarnya ganti kerugian yang diberikan oleh Pemerintah sedangkan kegiatan pengadaan tanah untuk kepentingan umum tersebut bersifat mendesak. Hal ini merupakan tugas yang cukup berat bagi Pemerintah dalam meng-ambil upaya alternatif dalam menyele-saikan hambatan dari kendala tersebut. Mekanisme musyawarah merupakan salah satu upaya awal untuk mencari jalan tengah (win-win solution) dalam menen-tukan besarnya ganti kerugian. Tetapi dalam mekanisme musyawarah ini juga terdapat kemungkinan bahwa dasar ketidaksepakatan mengenai ganti kerugian terjadi kembali.

Dengan dasar untuk kepentingan umum, Pemerintah melalui panitia penga-daan tanah untuk kepentingan umum dapat menentukan secara sepihak besar-nya ganti kerugian dan kemudian meni-tipkannya ke Pengadilan Negeri setempat melalui proses konsinyasi. Penerapan lem-baga konsinyasi dalam pengadaan tanah untuk kepentingan umum diharapkan mampu sebagai alternatif penyelesaian konflik antara pemegang hak atas tanah dengan Pemerintah. 
RUMUSAN MASALAH

1. Apa ratio legis pembentukan lembaga konsinyasi dalam pengadaan tanah untuk kepentingan umum?

2. Bagaimana prosedur pemberian ganti kerugian dalam pengadaan tanah untuk kepentingan umum?

\section{METODE PENELITIAN}

Metode yang digunakan dalam penelitian ini adalah metode penelitian yuridis normatif yang menekankan pada norma-norma hukum dengan menganalisa peraturan perundangundangan terkait.

Dalam Penelitian ini peneliti meng-gunakan dua metode pendekatan masalah yaitu :

a. Statute Approach, yaitu pendekatan dengan menelaah semua Peraturan Perundang-Undangan yang bersangkut paut dengan permasalahan (isu hukum) yang sedang dihadapi.

b. Conseptual Approach, yaitu pendekatan yang beranjak dari pandanganpandangan dan doktrin-doktrin yang berkembang di dalam ilmu hukum.

\section{PEMBAHASAN}

Ratio Legis Pembentukan Lembaga Konsinyasi
Pembangunan daerah merupakan isu yang paling sering kita temui dalam beberapa dekade kepemimpinan di Negara ini, seiring dengan bergantinya kepemim-pinan pemerintahan, pembangunan tetap merupakan salah satu tugas yang turun temurun ingin diwujudkan agar dapat bertahan dalam era global yang serba dinamis dan selalu berkembang demi menunjang kesejahteraan masyarakat. Untuk mewujudkan pembangunan ter-sebut tentunya harus membutuhkan tanah yang menjadi tapak dari terciptanya suatu pembangunan, namun pada kenyataannya tanah yang tersedia seringkali tidak memadai, sehingga diperlukan tanah masyarakat guna pembangunan tersebut, yang disebut juga pengadaan tanah yang menurut undang-undang dilakukan oleh pemerintah dengan memberi ganti kerugian kepada masyarakat yang memegang hak atas tanah tersebut.

Tanah memiliki 2 arti penting dalam kehidupan manusia, yaitu sebagai social asset dan capital asset. Tanah sebagai social asset adalah sebagai sarana pengikat kesatuan di kalangan lingkungan sosial untuk kehidupan dan hidup, se-dangkan tanah sebagai capital asset ada-lah sebagai modal dalam 
pembangunan dan telah tumbuh sebagai benda ekonomi yang sangat penting sekaligus sebagai bahan perniagaan dan objek spekulasi. ${ }^{3}$

Tanah merupakan sumber daya alam yang strategis bagi bangsa, Negara dan rakyat, dan diatur dalam Konstitusi Pasal 33 ayat (3) Undang-Undang Dasar 1945 menjelaskan bahwa segala kekayaan alam dikuasai oleh Negara. Kewenangan Nega-ra ini diatur dalam Pasal 2 UUPA yang antara lain :

1. Mengatur dan menyelenggarakan peruntukan, penggunaan, persediaan dan pemeliharaan bumi, air dan ruang ang-kasa

2. Menentukan dan mengatur hubunganhubungan hukum antara orang-orang dan perbuatan-perbuatan hukum yang mengenai bumi, air dan ruang angkasa

Saat ini kebutuhan tanah sebagai capital asset semakin meningkat, sebab banyaknya pembangunan dibidang fisik baik di perkotaan maupun pedesaan. Kebutuhan akan tersedianya tanah untuk keperluan pembangunan tersebut member-kan peluang terjadinya pengambilalihan tanah bagi kepentingan

3 Achmad Rubaie, Hukum Pengadaan Tanah Untuk Kepentingan Umum, Bayumedia, Malang, 2007, h. 1 umum. Keter-batasan tanah dan banyaknya pembang-unan menyebabkan pergesekan. Disatu sisi pembangunan sangat memerlukan tanah sebagai sarana utamanya, sedangkan disisi lain sebagian besar warga masya-rakat juga memerlukan tanah sebagai tem-pat permukiman dan tempat mata pencariannya. $^{4}$

Untuk itu Pemerintah perlu mengeluarkan kebijakan agar pembangunan dapat tetap terlaksana, khususnya pembangunan berbagai infrastruktur untuk kepentingan umum. Dan untuk memperoleh tanah-tanah tersebut dilaksanakan melalui pengadaan tanah untuk kepentingan umum. Landasan utama pengaturan pengadaan tanah ini ada dalam Pasal 18 UUPA "Untuk kepentingan umum, ter-masuk kepentingan bangsa dan Negara serta kepentingan bersama dari rakyat, hakhak atas tanah dapat dicabut dengan memberi ganti kerugian yang layak dan menurut cara-cara yang diatur UndangUndang”.

Walaupun di dalam Pasal 21, 29, 42 dan 45 UUPA mengandung prinsip penguasaan dan penggunaan tanah 4 Abdurrahman, Masalah Pencabutan HakHak Atas Tanah dan Pembebasan Tanah di Indonesia,Edisi Revisi, Citra Aditya Bakti, Banding, 1991, h.9 
secara individu, namun hak-hak atas tanah yang bersifat pribadi tersebut mengandung fungsi sosial yang dipertegas dalam Pasal 6 UUPA.

Di satu sisi, negara menjamin kepe-milikan yang sah individu atas tanah sebagaimana diamanatkan dalam Undang-Undang Dasar 1945 dan Undang-Undang Pokok Agraria, di sisi lain pelaksana kekuasaan negara, yakni pemerintah, berkewajiban menjalankan agenda pem-bangunan infrastruktur fisik yang kerap kali harus mengorbankan nilai kepen-tingan individu. Akomodasi secara kon-septual terhadap kedua kepentingan itu sebenarnya sudah ada sejak tahun 1960 pada saat UndangUndang Pokok Agraria dibentuk dalam Undang-Undang tersebut kedua kepentingan itu sudah diletakkan secara hierarki pada tingkat kepentingan yang saling mengimbangi. Hak atas tanah apapun yang ada ada seseorang tidaklah dapat dibenarkan bahwa tanahnya itu akan dipergunakan atau tidak dipergunakan semata-mata untuk kepentingan priba-dinya, apalagi kalau hal itu menimbulkan kerugian bagi masyarakat.

Secara normatif semua hak atas tanah mempunyai fungsi sosial, oleh sebab itu pemerintah mengeluarkan kebijakan dalam pengadaan tanah untuk kepentingan umum karena pembangunan tetap harus terlaksana, hal itulah yang menjadi latar belakang pemerintah menitipkan ganti kerugian melalui Pengadilan Negeri bagi pihak yang berhak atas tanah yang keberatan terhadap hasil musyawarah setelah melalui prosedur dan mekanisme pelepasan hak oleh panitia pengadaan tanah untuk kepentingan umum yang telah diatur dalam ketentuan perundang-undangan.

Selain dari kebijakan pemerintah untuk menitipkan hasil ganti kerugian dalam pengadaan tanah untuk kepentingan umum adalah agar tercipta kepastian hukum mengenai status tanah yang akan digunakan pemerintah untuk pembang-unan, dengan dititipkannya ganti kerugian tersebut pada Pengadilan Negeri maka tanah tersebut menjadi tanah negara berdasarkan peraturan perundang-undang-an.

Sehingga tujuan dari pada dititipkannya ganti kerugian kepada Pengadilan Negeri selain daripada hal yang telah diuraikan tersebut adalah untuk memberi-kan kepastian hukum atas penyerahan ganti kerugian oleh negara terhadap pemegang hak atas tanah yang tanahnya diambilalih oleh negara melalui prosedur dan mekanisme 
yang telah ditetapkan oleh UndangUndang.

Penggunaan lembaga konsinyasi merupakan salah satu cara untuk memaksa masyarakat dalam rangka pengambil-alihan tanah masyarakat setelah melalui prosedur yang ditetapkan oleh Peraturan Perundang Undangan merupakan dasar hukum untuk melakukan pembayaran ganti kerugian kepada pihak yang berhak atas atas yang mengajukan keberatan atas hasil musyawarah penetapan nilai ganti kerugian. Konsinyasi seperti diatur dalam Pasal 1404 Kitab Undang-Undang Hukum Perdata, merupakan opsi yang ditawarkan oleh undang-undang bagi debitur untuk melunasi piutang terhadap kreditur, dengan kondisi kreditur menolak pena-waran pembayaran yang dilakukan oleh debitur, sehingga jika berpedoman pada pengertian konsinyasi pada Pasal 1404 Kitab Undang-Undang Hukum Perdata, kita wajib menelaah lebih jauh apakah penerapan lembaga konsinyasi memang dapat diterapkan dalam masalah penen-tuan ganti kerugian yang telah memenuhi syarat musyawarah untuk mufakat. Dalam pengadaaan tanah demi kepentingan umum inilah yang sering menimbulkan masalah penentuan ganti kerugian yang dilakukan melalui konsinyasi (penitipan).

Lembaga konsinyasi yang diterapkan dalam pengadaan tanah sesungguhnya merupa-kan langkah terakhir yang diambil oleh pemerintah sehubungan dengan pengambilalihan tanah agar tidak lagi terjadi perampasan tanah masyarakat yang diperoleh sesuai prosedur, sehingga peme-rintah diharapkan agar dapat menciptakan kesinambungan antara kepentingan umum dengan kepentingan rakyat.

Perolehan tanah dalam pengadaan tanah untuk kepentingan umum oleh Pemerintah dilaksanakan dengan cara pelepasan atau penyerahan hak atas tanah. Ganti kerugian dalam pengadaan tanah untuk kepentingan umum diberikan untuk hak atas tanah, bangunan, tanaman, dan benda-benda lain yang berkaitan dengan tanah. Bentuknya dapat berupa uang, tanah pengganti, pemukiman kembali, dan/atau bentuk lain yang disetujui pihak-pihak yang bersangkutan. Musyawarah menghasilkan dua kemungkinan, yaitu kesepakatan, dan kedua tidak mencapai kesepakatan mengenai bentuk dan besarnya ganti kerugian antara pemegang hak atas tanah, instansi Pemerintah yang 
memerlukan tanah, dan Panitia Pengadaan Tanah.

Prosedur Pemberian Ganti Kerugian

Dalam Pengadaan Tanah Untuk

\section{Kepentingan Umum}

Proses penetapan ganti kerugian dalam pengadaan tanah untuk kepentingan umum diatur dalam Pasal 37 Undang-Undang Nomor 2 Tahun 2012 jo. Pasal 68, Peraturan Presiden Nomor 71 Tahun 2012 juncto Menurut ketentuan ini, penetapan ganti kerugian dilakukan dalam proses musyawarah secara langsung anta-ra para pihak (instansi yang memerlukan tanah dan pemegang hak atas tanah) serta dipimpin oleh Lembaga Pertanahan/BPN sebagai pelaksana pengadaan tanah.

Proses musyawarah tersebut dilakukan dalam waktu 30 hari sejak hasil pe-nilaian dari penilai disampaikan kepada lembaga penilai (Ketua Pelaksana Penga-daan Tanah).

Pelaksanaan musyawarah dapat dibagi dalam beberapa kelompok dengan mempertimbangkan jumlah pihak yang berhak, waktu dan tempat pelak-sanaan musyawarah.

Dalam hal pihak yang berhak berha-langan hadir dalam proses musyawarah tersebut, yang bersangkutan dapat mem-berikan kuasa kepada pihak lain seperti yang ditentukan dalam Pasal 71 Peraturan Presiden Nomor 71 Tahun 2012, yaitu:

1. Seorang dalam hubungan darah keatas, kebawah atau kesamping sampai derajat kedua atau suami/ istri bagi pihak yang berstatus perorangan

2. Seorang yang ditunjuk sesuai dengan ketentuan anggaran dasar bagi pihak yang berhak berstatus badan hukum atau

3. Pihak yang berhak lainnya, serta

4. Kuasa itu hanya dapat diberikan kepada satu orang penerima kuasa atas satu atau beberapa bidang tanah yang terletak pada satu lokasi pengadaan tanah

Jika pihak yang berhak tidak hadir dalam proses musyawarah tersebut, sedangkan undangan sudah disampaikan secara patut, serta tidak pula menunjuk kuasanya, maka yang berhak dianggap menerima dan/atau menyetujui bentuk dan besarnya ganti kerugian yang ditetapkan oleh pelaksana pengadaan tanah.

Dalam musyawarah tersebut menu-rut Pasal 70 ayat 2 Peraturan Presiden Nomor 71 Tahun 2012, dapat dilaksana-kan lebih dari satu kali. Pelaksana pengadaan tanah menyampaikan besarnya ganti kerugian 
hasil penilaian dari penilai. Jika terjadi kesepakatan tentang besar dan bentuk ganti kerugian, akan dituangkan dalam berita acara kesepakatan, yang kemudian dipakai sebagai dasar pemba-yaran ganti kerugian.

Dalam hal tidak terjadi kesepakatan mengenai bentuk dan besar ganti keru-gian, menurut Pasal 73 Peraturan Presiden Nomor 71 Tahun 2012, pihak yang berhak dapat mengajukan keberatan (dengan cara mengajukan gugatan) kepada Pengadilan Negeri setempat dalam waktu 14 hari kerja setelah ditandatangani berita acara hasil musyawarah. Pengadilan Negeri memutus bentuk dan atau besarnya ganti kerugian dalam waktu paling lama 30 hari sejak diterimanya pengajuan keberatan. Putusan Pengadilan Negeri ini belum final, sehingga bagi pihak yang berhak berkeberatan maka dalam waktu 14 hari kerja dapat mengajukan kasasi ke Mahka-mah Agung, dan harus diputus dalam waktu paling lama 30 hari sejak permo-honan kasasi diterima.

Memperhatikan proses musyawarah dalam hal penetapan bentuk dan utamanya besarnya ganti kerugian dalam pengadaan tanah untuk kepentingan umum yang seperti terurai diatas, menunjukkan posisi pihak yang berhak (pemegang hak atas tanah) dalam posisi yang lemah. Besarnya ganti kerugian ditetapkan oleh Penilai Pertanahan yang dalam proses penilaiannya tidak disertai dengan standar penilaian yang dirumuskan dalam peraturan hukum.

Tidak dijelaskan pula dalam Undang-Undang Nomor 2 Tahun 2012 beserta peraturan pelaksananya tentang posisi dari hasil penilaian Penilai yang menyangkut besarnya ganti kerugian, bersifat final atau masih bisa berubah sesuai dengan dinamika yang ada dalam proses musyawarah. Kalau itu bersifat final, maka proses musyawarah itu sekedar proses legitimasi semata atas hasil penilaian dari Penilai tanpa memper-timbangkan pendapat dan kepentingan dari pemegang hak atas tanah.

Alangkah baiknya bila definisi musyawarah dirumuskan dalam Peraturan Presiden Nomor 71 Tahun 2012 sebagai aturan pelaksana dari Undang-Undang Nomor 2 Tahun 2012 yang memberikan pengertian musyawarah adalah kegiatan yang mengandung proses saling men-dengar, saling memberi dan saling menerima pendapat, serta keinginan untuk mencapai kesepakatan mengenai besar 
dan bentuk ganti kerugian dan masalah lain yang berkaitan dengan kegiatan pengadaan tanah atas dasar kesukarelaan dan kesetaraan antara pihak yang mempunyai tanah, bangunan, tanaman dan benda-benda lain yang berkaitan dengan tanah dengan pihak yang memerlukan tanah.

Sedangkan pengertian musyawarah tidak diatur dalam Undang-Undang Nomor 2 Tahun 2012, melainkan musyawarah dalam konsteks konsultasi publik. Seperti yang tercantum dalam Pasal 1 angka 8 yang berbunyi Konsultasi Publik adalah proses komunikasi dialogis atau musyawarah antar pihak yang berkepentingan guna mencapai kesepahaman dan kesepakatan dalam perencanaan pengadaan tanah bagi pembangunan untuk kepentingan umum. Jadi musyawarah dalam konteks konsultasi publik hanya terkait dengan tahapan perencanaan dan bukan tahap pelaksanaan.

Konsinyasi ganti kerugian muncul dalam praktek saat terjadi dead lock dalam musyawarah penentuan bentuk dan besar ganti kerugian dalam pelaksanaan penga-daan tanah untuk kepentingan umum yang dilakukan dengan mendasarkan pada Permendagri Nomor 15 Tahun 1975.
Untuk menjamin objektivitas dalam menentukan apakah pengadaan tanah itu telah memenuhi syarat atau tidak sebagai pengadaan tanah yang lokasinya tidak dapat dipindahkan, penilaiannya dan/ atau penetapannya yang bersfiat sepihak dan tidak objektif. Lembaga tersebut bisa saja diserahkan pada Pengadilan yang sebelum melakukan penetapan dapat memanggil dan mendengarkan serta mempertimbangkan pendapat dan keterangan para pihak dan saksi yang berkompeten di bidangnya.

Pada era berlakunya UndangUndang Nomor 2 Tahun 2012, penitipan uang ganti kerugian (konsinyasi) diatur dalam Pasal 42 dan 43 serta dalam Pasal 86 sampai dengan Pasal 95 Peraturan Presiden Nomor 71 Tahun 2012. Disebutkan bahwa penitipan uang ganti kerugian dilakukan di Pengadilan Negeri pada wilayah lokasi pembangunan untuk kepentingan umum, dan itu dilakukan dalam hal:

1. Pihak yang berhak menolak bentuk dan/atau besar ganti kerugian berdasarkan hasil musyawarah dan tidak mengajukan keberatan ke Pengadilan

2. Pihak yang berhak menolak bentuk dan/atau besar ganti kerugian berdasarkan putusan Pengadilan Negeri/ 
Mahkamah Agung yang telah memper-oleh kekuatan hukum tetap

3. Pihak yang berhak tidak diketahui keberadaannya

4. Objek pengadaan tanah yang akan diberikan ganti kerugian :

a. Sedang menjadi objek perkara di Pengadilan

b. Masih dipersengketakan kepemilikannya

c. Diletakkan sita oleh pejabat yang berwenang

d. Menjadi jaminan Bank

Pada dasarnya lembaga konsinyasi diambil dari lembaga yang diatur dalam Buku III BW, seperti halnya ganti kerugian yang sudah dibahs sebelumnya. Pasal 1404 BW menyatakan Jika si berpiutang menolak pembayaran, maka di berpiutang dapat melakukan penawaran pembayaran atau barangnya kepada Pengadilan. Penawaran demikian, diikuti dengan penitipan, membebaskan si berpiutang dan berlaku baginya sebagai pembayaran, asal penawaran itu dilakukan dengan cara menurut Undang-Undang, sedangkan apa yang dititipkan itu tetap atas tanggungan di berpiutang

\section{PENUTUP}

\section{Kesimpulan}

1. Berdasarkan pembahasan ratio legis pembentukan lembaga konsinyasi dalam pengadaan tanah untuk kepentingan umum adalah untuk memberikan kepastian hukum atas berjalannya agenda pembangunan nasional yang telah direncanakan Pemerintah, untuk memberikan kepastian hukum terhadap status tanah yang digunakan Peme-rintah dalam rangka pengadaan tanah untuk kepentingan umum dan untuk memberikan kepastian hukum atas penyerahan ganti kerugian oleh negara terhadap pemegang hak atas tanah yang tanahnya diambilalih oleh negara

(1) Prosedur pemberian ganti kerugian dalam pengadaan tanah untuk kepentingan umum yang harus dilaksanakan oleh Pemerintah meliputi Tahap Perencanaan, Tahap Persiapan, Tahap Pelaksanaan dan Tahap Penyerahan hasil.

\section{Saran}

1. Untuk mempermudah penyerahan ganti kerugian kepada pemegang hak atas tanah maka sebaiknya Pengadilan Negeri sebagai pelaksana dari lembaga konsinyasi berperan aktif untuk mempermudah proses 
penyerahan ganti kerugian kepada pemegang hak atas tanah.

2. Untuk menghindari kerugian yang diderita oleh masyarakat di dalam proses pengadaan tanah untuk kepentingan umum sebaiknya pemerintah melibatkan masyarakat khususnya yang berpotensi terkena dampak pengadaan tanah untuk kepentingan umum
Abdurrahman, Masalah Pencabutan Hak-Hak Atas Tanah dan Pembebasan Tanah di Indonesia, Edisi Revisi, Citra Aditya Bakti, Banding, 1991

Achmad Rubaie, Hukum Pengadaan Tanah Untuk Kepentingan Umum, Bayumedia, Malang, 2007

Herman Hermit, Cara Memperoleh Sertipikat Tanah Hak Milik, Tanah Negara dan Tanah Pemda,Mandar Maju, Bandung, 2004.

SF. Marbun dan Mahfud MD. PokokPokok Hukum Administrasi Negara. Liberty, Jogjakarta, 2010.

\section{DAFTAR PUSTAKA}

